\title{
Article
}

\section{EAL Writers and Peer Tutors: Pedagogies that Resist the "Broken Writer" Myth}

Daniel Chang and Amanda Goldrick-Jones Simon Fraser University

\section{Abstract}

Writing centres offer a safe space for writers, including English-as-additional-language (EAL) students, to negotiate meaning and become more fluent with academic writing genres. However, a disconnect still exists between the writer-centred principles that inform WC tutoring practice and the pervasive myth that writing centres repair "broken" writing. An analysis of data from a writing centre's client reports, as well as peer tutors' comments and student writing samples, indicates that a student's language membership does not predict types of writing challenges or errors. This finding inspired a roundtable discussion about pedagogical approaches that not only empower EAL students but help writing centres resist the "broken writer" myth.

Keywords: EAL writers, writing centres, peer tutors, peer training, writing community, empowerment

Many writing centre (WC) tutors encounter the challenge of giving feedback on post-secondary English-as-additional-language (EAL or ESL) students' writing. Conferencing/tutoring strategies for native English-speaking writers do not always work for EAL writers (Moussu, 2013). For example, EAL writers might not notice errors when they are asked to read their work out loud, or they might not possess the same linguistic intuition as native English-speaking writers. But to what extent should peer-tutor training focus on EAL issues or errors? Is there a danger of stigmatizing EAL writers?

As Terese Thonus (1993) has argued, tutoring that focuses "attention to grammar and mechanics after organization and development" (p. 20) can benefit native and non-native-English writers equally, but only if the student writer participates in "the negotiation of meaning" (p. 20). Such negotiation can be seen as a process of helping EAL writers articulate higher-order elements as purpose, structure, and key arguments, thus encouraging and empowering them to take ownership of their 
Volume 29, 2019

http://journals.sfu.ca/cjsdw

whole piece. Essential to the writer's process of negotiating meaning, Thonus suggests, is the interaction of peer, tutor, and instructor comments. We believe instructors can do more to help writers and instructors re-vision the WC as a site for negotiating meaning.

Post-secondary instructors often refer EAL students to writing centres for improving writing skills. However, a disconnect still exists between the writer-centred principles that inform WC tutoring practice-most famously articulated by Stephen North—and what some instructors (and desperate students) think writing centres should do: "fix" or "clean up" the writing. Indeed, a basic principle of WC training is that tutors do not directly edit or proofread student essays (Myers, 2003). A recent news bulletin from the University of Victoria has clearly stated the position that editing undergraduate student essays or lab assignments is considered to be a violation of academic integrity (Woollard, 2017). Yet as Thonus noted over twenty years ago, WC tutors did and still do experience pressures to "fix" errors-pressures resulting at worst in a scenario where "the frustrated ESL student and equally frustrated tutor square off against one another" (1993, p. 21).

At our roundtable at the May 2018 CWCA conference, we opened discussion by sharing highlights of research we are currently conducting in our Student Learning Commons at Simon Fraser University, in which we explore WC tutoring strategies that meet the challenges of giving feedback to EAL writers without crossing the boundary into editing. The SLC uses a peer-tutoring model in which trained undergraduate students provide one-on-one consultations. Data collected from undergraduate writers since early 2017 include electronic appointment information, tutors' reports on EAL consultations, and student writing samples with revisions based on tutors' feedback.

Statistical analyses of the appointment data and tutors' responses show that a student's language membership does not predict types of writing challenges or errors: e.g. higher order concerns versus lower order concerns. This finding is quite promising because in second language acquisition (SLA) literature, EAL writers have been seen from a deficit-oriented perspective (Guo, 2015; Marshall, 2012; Tangen \& Spooner-Lane, 2008). Postsecondary teachers might stereotypically assume that all EAL writers' work will have grammatical errors and that the written products might not be as good as the work produced by native English-speaking students.

This assumption explains, at least partly, why instructors tend to refer EAL writers to the writing centre to "repair" the grammar. Particularly, Anthony Paré of the University of British Columbia has pointed out how instructors conceptualize the "writing centre ... [as] a place to 'send the broken students'” (Heng Hartse, 2016). Paré suggests writing centres exacerbate this misconception themselves because they tend to operate as a "cross-curriculum" general writing tutorial service in some North 
Volume 29, 2019

http://journals.sfu.ca/cjsdw

American post-secondary institutions. They lack content-area or discipline-specific writing expertise to support writing issues beyond "just fixing up the grammar."

However, our research suggests that writing challenges are in fact cross-disciplinary; every postsecondary writer has writing challenges, regardless of discipline, linguistic membership, writing abilities, or academic residency. In other words, regardless of whether they are native English-speaking students or EAL students, undergraduate writers benefit from a tutorial approach focusing primarily on higher-order concerns. Such concerns are frequently discipline-specific or genre-related, which all academic writers must negotiate. To that end, WCs can benefit from appointing peer tutors from a range of disciplines and inviting student writers to work with peers who are familiar with their particular discipline. This approach allows the WC to become a space for not only negotiating meaning across disciplines to reach a broad range of audiences, but also familiarizing writers with specific genre expectations.

We invited discussion from the roundtable about what pedagogical approaches can help peer tutors not only empower EAL students but resist the "broken writer" myth. For tutor training, our roundtable participants stressed how important it is not to insist on a rigid hierarchy of which higheror lower-order concerns to address, nor to impose a process or practice that could be dismissive of what students need. Flexibility should be central: at times, lower-order concerns can serve as a pathway to higher-order issues. The goal is to let all writers feel they're being listened to or acknowledged.

These comments resonated with another finding from our research: that the most frequently reported EAL writing challenges are sentence logic and word usage. It is understandable that EAL writers need time to formulate their thoughts and translate thoughts into sentences. Sometimes, during the process, the logical structures of the sentences might be lost due to either interference from their first language or their lack of language proficiency (Silva, 1992; Watcharapunyawong \& Usaha, 2013). This finding suggests that writing centres should be a safe space for negotiating this level of meaning as well, allowing writers and tutors to co-construct or scaffold meaning and develop their own awareness of sentence structure through feedback.

When giving feedback, peer tutors try to elicit self-corrections through questions or prompts. But as noted earlier, this time-tested Socratic approach may place a great deal of stress on an EAL writer who hasn't yet learned a particular rule or usage. If EAL students see their writing as "broken," quite understandably they may come to writing tutors with the expectation their writing will be "repaired." Is correction ever an appropriate strategy? Does it veer toward plagiarism? When we put these questions to our roundtable participants, they suggested WCs should "push back a bit" against concerns 
Volume 29, 2019

http://journals.sfu.ca/cjsdw

about "over-editing." Multilingual students naturally seek editing help: why is this a bad thing? And is it a bad thing to write on someone else's paper: alongside or in the margins, as part of a conversation around meaning?

Our roundtable participants maintained that editorial feedback is integral to everyone's writing process and that, like other parts of that process, it's seldom done in isolation. A useful taxonomy for giving such feedback to EAL students (Ellis 2008), originally proposed for oral communication, can also transfer to or work for the WC tutoring process. The best example of using these strategies in WC tutoring practice is to recast (or clarify) students' meaning of sentences on paper and provide opportunities for the students to negotiate their meaning with the tutor. That is, if a student paper contains incomprehensible sentences, the tutors can implicitly point out the difficult-to-understand sentences and then ask the students for meaning clarification (Ellis, 2008).

While EAL students require additional support in their writing, our research indicates that one's linguistic membership does not predict the types of writing challenges a student will encounter. As one roundtable participant aptly put it, "Academic English is no one's first language." Both across and within disciplines, student writers share the same likelihood of having writing issues. Labelling student writers according to their linguistic membership or writing ability might not be the best way to give support or to frame a referral to the WC. Although EAL writers tend to struggle more than native speakers with second-order issues such as sentence logic and word usage, the WC can train tutors to use support strategies that apply to all writers, such as recast or clarification, to accommodate a range of writing issues.

Are there other proactive ways to resist the myth that writing centres are repair shops for "broken writers"? Roundtable participants discussed how extending writing-centre tutoring into undergraduate classes-not only giving workshops but integrating writing support dynamically with particular writing assignments-could empower all students and support disciplinary instructors. Writing centres can also play a vital role in raising awareness of academic English as a colonizing force, how such colonization perpetuates deficit discourse, and how we can revise those assumptions. In this re-visioning, writing centres become spaces where students experience, and are supported in, a dynamic process of constructing meaning and becoming part of a writing community.

\section{References}

Ellis, R. (2008). A typology of written corrective feedback types. ELT journal, 63(2), 97-107. 
Volume 29, 2019

http://journals.sfu.ca/cjsdw

Guo, Y. (2015). 'Unlearning Privileges': Interrupting Pre-Service Teachers Deficit Thinking of Immigrant Students with Origins in the South. Cultural and Pedagogical Inquiry, 7(1), 34-59.

Heng Hartse, J. (Producer). (2016). Episode 2 - Academic Writing in Canada with Dr. Anthony Paré [Audio podcast]. Retrieved from https://www.sfu.ca/celltr/faculty-development/languageu-podcast.html

Marshall, S. (2009). Re-becoming ESL: Multilingual university students and a deficit identity. Language and Education, 24(1), 41-56.

Moussu, L. (2013). Let's Talk! ESL Students' Needs and Writing Centre Philosophy. TESL Canada Journal, 30(2), 55-68.

Myers, S. (2003). Reassessing the "proofreading trap": ESL tutoring and writing instruction. Writing Center Journal, 24(1), 51-70.

Silva, T. (1992). L1 vs L2 writing; ESL graduate students' perceptions. TESL Canada Journal, 10(1), 27-47.

Tangen, D., \& Spooner-Lane, R. (2008). Avoiding the deficit model of teaching: Students who have EAL/EAL and learning difficulties. Australian Journal of Learning Difficulties, 13(2), 63-71.

Thonus, T. (1993). Tutors as teachers: Assisting ESL/EFL students in the writing center. The writing center journal, 13(2), 13-26.

Watcharapunyawong, S., \& Usaha, S. (2013). Thai EFL Students' Writing Errors in Different Text Types: The Interference of the First Language. English Language Teaching, 6(1), 67-78.

Woollard. J. (2017, Aug 25). A fine red line: when does editing a student's work become cheating?. University Affairs/Affaires universitaires. Retrieved from http://www.universityaffairs.ca/news/news-article 